\title{
Lançamento do Livro Adoção e Legitimação Adotiva do Professor Antonio Chaves*.
}

Constituíu acontecimento social de grande relêvo o Iançamento oficial do recente livro do Professor Antonio Chaves - Adoção e Legitimação Adotiva - promovido pela Editôra "Revista dos Tribunais" Ltda., com o honroso patrocínio do Tribunal de Justiça de São Paulo.

À reunião festiva, que teve lugar às 17 horas do dia 24 de junho último, na Livraria "Revista dos Tribunais", à Rua Conde do Pinhal n. 78, ao lado do Forum João Mendes Júnior, compareceu o que há de mais expressivo em nosso meio social e jurídico: desembargadores, ministros, membros do Ministério Público, juízes de direito, professôres universitários, advogados, parlamentares, e inúmeras pessoas especialmente convidadas.

O Dr. Nelson Palma Travassos, Diretor da Editôra promotora do lançamento, fêz uma breve saudação aos presentes, dizendo da alegria que a Casa sentia pela oportunidade de reunir, para o lançamento de uma grande obra, tão significativo número de amigos. Passou, a seguir, a palavra ao Dr. Lauro Malheiros, Diretor-responsável da "Revista dos Tribunais", o qual pronunciou a seguinte oração:

"É com a mais grata satisfação que a Editôra "Revista dos Tribunais" faz hoje o lançamento oficial do livro do Professor Antonio Chaves - Adoção e Legitimaçẫo Adotiva.

\footnotetext{
* Transcrito da Revista dos Tribunais.
} 
Trata-se da dissertação com que S. Exa., em recente e memorável concurso, conquistou, com distinção, a cátedra de Direito Civil da Faculdade de Direito da Universidade de São Paulo, depois de ter obtido, em concursos anteriores, a livre-docência da mesma cadeira e da de Direito Internacional Privado.

Com essas credenciais do ilustre mestre, a obra se apresenta ao grande público, para passar a ter, com certeza, um lugar de destaque na literatura jurídica pátria.

Na verdade, é o primeiro trabalho de fôlego, de profundidade e extensão, sôbre os institutos da adoção e da legitimação adotiva.

Trabalhador infatigável, brilhante colaborador da Revista dos Tribunais, magistrado operoso e impoluto, autor de numerosas obras internacionalmente conhecidas, professor há longos anos em nosso magistério superior e agora titular, na Faculdade do Largo de São Francisco, da cátedra de onde irradiou a luz fulgurante de Vicente Ráo tem ainda o Dr. Antonio Chaves, a exornar a sua personalidade, uma qualidade moral que mais o engrandece: a sua encantadora modéstia.

Jamais se jactou de sua sabedoria, jamais fêz alarde do que construía silenciosamente, com paciência beneditina, aproveitando tôdas as horas de lazer, sempre voltado para o estudo.

Eis porque aprouve a esta Editôra, com o gentil apoio de S. Exa. o Sr. Des. Raphael de Barros Monteiro, digníssimo Presidente do Tribunal de Justiça de São Paulo, dar realce a êste acontecimento, como justa homenagem a êsse jurista ainda jovem, em quem não sabemos o que mais admirar: o magistrado ou o mestre de direito, tal o brilho com que exerce ambas as funções. Por certo não dormirá S. Exa. sôbre os louros e nos brindará com novas obras jurídicas, mormente agora que se acena com uma completa reformulação de quase todos os ramos do Direito. 
Ł justo que esta homenagem seja extensiva a Exma. Espôsa do Dr. Antonio Chaves, companheira dedicada e incansável de suas vigilias, anjo tutelar que o incentivotz e inspirou na conquista dos galardões que ostenta.

A ela também pertence esta festividade.

Congratulando-se, portanto, com os nossos meios juridicos pelo lançamento desta obra notável, esta Editôra vale-se dêste ensejo para agradecer, muito penhorada, a amável presença, em sua casa, de tão conspícuos magistrados, professôres membros do Ministério Público, advogados, amigos e admiradores do Professor Antônio Chaves, a quem cumprimenta muito cordialmente e a quem deseja tôda sorte de venturas".

A seguir, usou da palavra S. Exa. o Sr. Des. Raphael de Barros Monteiro, Presidente do Tribunal de Justiça de São Paulo, que assim se pronunciou:

"Meus Senhores,

Exmas. Senhoras:

Idéia feliz teve a Emprêsa Gráfica da "Revista dos Tribunais" de promover o lançamento da obra Adoção $e$ Legitimação Adotiva, do ilustre Professor e Magistrado Antônio Chaves, em tarde festiva e perante o mundo social e jurídico de São Paulo.

O nome do Juiz e Professor Antônio Chaves dispensa apresentação: desde os idos de 1945, quando publicou a monografia intitulada $O s$ Súditos Inimigos e o Direito de Guerra Brasileiro, que mereceu o primeiro prêmio conferido pelo Instituto dos Advogados de São Paulo e os mais desvanecedores elogios de juristas, ministros e desembargadores, aqui e no exterior, tudo estava a indicar que não iria o então jovem cultor do Direito ficar ùnicamente naquele livro, prosseguindo, ao contrário, na sua senda de trabalhador apaixonado e infatigável. 
Aí estão as conferências, artigos e trabalhos juridicos que se seguiram, que peço permissão para alinhar ràpidamente, porque estampados em publicações esparsas e só conhecidas de pessoas altamente especializadas:

A conferência subordinada ao tema Liberação dos bens dos súditos inimigos, publicada na imprensa e na Revista dos Tribunais; os artigos Condição jurídica dos estrangeiros no Brasil e Direitos dos artistas-intérpretes em matéria de radiodifusão, também publicados na mesma "Revista"; a monografia Normas nacionalizadoras do direito brasileiro, publicada em 1950; o estudo $O$ direito do autor no Brasil, em 1950, trabalho de capital importância como contribuição à divulgaçãó, no estrangeiro, da cultura jurídica nacional; dois outros artigos, publicados em língua francesa e inglêsa, sôbre direito do autor em cinematografia e na radiodifusão, bem como um outro sôbre a Proteção legal das obras fotográficas, mais dois artigos, um sôbre a Lei determinadora do fôro competente para o inventário e partilha de bens imóveis deixados no Brasil por estrangeiro falecido no exterior, e outro, sôbre o Casamento das qüinqüagenárias e dos sexagenários; a monografia Direito autoral de radiodifusão, favoràvelmente acolhido pelas críticas nacional e estrangeira.

Culminou a atividade do Professor com a publicação de duas obras que, sem favor nenhum, podem ser colocadas no ápice do pensamento jurídico em nossa Terra: as Segundas Núpcias, Adoção e Legitimação Adotiva, que ora é oficialmente lançada.

Da primeira, tive a oportunidade de manifestar a minha desvaliosa opinião a vários colegas juristas, sem que tal importasse em desmerecimento a quaisquer outros, que fôra o melhor trabalho jurídico que lera nos últimos tempos.

Não sem razão, portanto, que vieram as Segundas Núpcias a repercutir no estrangeiro, onde, no Canadá, teve 
o Juiz Landreville, da Suprema Côrte de Ontário, oportunidade de aplicá-las em caso sob a sua jurisdição.

Pedindo escusas à modéstia do Professor Antônio Chaves, não me furto ao prazer de ler a carta que, a respeito, o Juiz Landreville lhe enviou. E curta, mas significativa:

“É com prazer que reconheço o auxílio que o volume Segundas Núpcias me proporcionou na interpretação das leis pertinentes ao casamento.

Naturalmente, êste aspecto do Direito é sempre interessante por ser de ampla aplicação. Jamais é estacionário.

Utilizei-me dêste volume para interpretar a lei brasileira num caso que envolvia duas pessoas de origem grega, as quais contraíram casamento religioso em São Paulo, tendo a minha decisão sido reexaminada esta semana pela Côrte de Apelação, que a confirmou.

Desnecessário dizer que estou muito grato ao autor, Antônio Chaves. Seu erudito trabalho contribuíu muito para nossa compreensão das leis brasileiras nesse âmbito, o que posso atestar".

Finalmente, dá o Professor Antonio Chaves a lume a obra que ora é lançada, Adoção e Legitimação Adotiva, o que lhe deu uma das cátedras de Direito Civil na nossa gloriosa Faculdade de Direito de São Paulo.

Não se pode negar a importância que hoje em dia volta a ter o instituto da adoção, principalmente o da legitimação adotiva, com razão considerada como uma das mais brilhantes conquistas de nosso século. "Tem poucos meses de vida", diz o Professor Antonio Chaves no preâmbulo do livro, "mas, agigantando-se, conquistará, ràpidamente, um pôsto relevantíssimo". 
Já entre os povos antigos, como mostra Martinho Garcez Neto, era a adoção considerada uma instituição de Direito Público, dada a importância inconteste que teve o instituto antigamente. Êsse o feitio, por igual, que lhe vem sendo atribuído modernamente, segundo a corrente a que pertence o Professor Antonio Chaves, para quem a adoção, que hoje ressurge com outras finalidades, entre elas a de proteção aos menores, é um instituto de ordem pública, embora para a sua virtualidade jurídica, em cada caso particular, dependa de um ato jurídico individual.

Tem-se aí uma pálida idéia da importância e do grande valor da obra que é hoje oficialmente entregue ao grande público pela Emprêsa Gráfica da "Revista dos Tribunais", que, por essa forma, presta um inestimável serviço às letras jurídicas nacionais.

Agradecendo a essa Editôra a honra que me foi concedida, como Presidente do Tribunal de Justiça do Estado, de ser patrono dêste lançamento, com os cumprimentos, e os de todos, ao seu autor, meu particular amigo, o insigne Professor Antônio Chaves, à sua Exma. Espôsa D. Eunice Chaves, e aos dignos filhos do casal, os meus votos, como os de todos os presentes, para que a obra agora lançada projete ainda mais o nome de nosso dileto amigo jurista nas letras juridicas de nossa Terra"

A seguir, agradecendo, o Professor Antônio Chaves assim discursou:

“É genuína e profunda a emoção que me faz estremecer no momento em que, sob os auspícios da mais alta autoridade do Poder Judiciário do Estado e na presença de tão luzida e numerosa representação de colegas e amigos, lança a tradicional Editôra "Revista dos Tribunais" a meu livro.

A própria terminologia indica que publicar um livro é, no plano espiritual, como que ter um filho no plano 
material, pois não encontra palavras senão idênticas para exprimir ambas as idéias: conceber, dar à luz, criar.

E como o nascimento de uma criança, assim também a gênese de um livro é cercada de uma auréola de sonhos, de esperanças, de ilusões.

Perdoai, por isso, meus amigos, que como pai "coruja" que se preze, enternecido e comovido, ressalte, nesta solenidade, três circunstâncias que lhe emprestam uma significação tôda especial.

Em primeiro lugar, o relêvo extraordinário de que a cerca o prestígio de Vossa Excelência, senhor Desembargador Raphael de Barros Monteiro, que não é só do cargo, mas, principalmente, da personalidade que o ocupa, numa demonstração que transcende de muito o simples gesto de fidalguia ou de amabilidade, para constituir uma verdadeira tomada de posição, franca, aberta, positiva, como são tôdas as tomadas de posição de Vossa Excelência.

Existe, na verdade, u'a mal dissimulada prevenção contra os magistrados que publicam livros, que escrevem, que lecionam em escolas superiores, que se especializam em suas pesquisas, que produzem, enfim, fora de suas atividades específicas.

Susurra-se, numa inculpação tão indiscriminada quão destituída de fundamento, que êles sacrificam suas funções judiciárias, não lhes dedicando a atenção indispensável.

Não se cogita comprovar se a acusação tem ou não fundamento, não se cuida de averiguar a capacidade de trabalho dos juízes publicistas e dos juízes professôres, não se procura verificar se êles desenvolvem ou não sua dúplice atividade imolando suas horas de repouso e de diversão, seus domingos, seus feriados e suas férias, sua própria existência, a de sua família, o convívio com amigos queridos. 
E êsse murmúrio estiriliza vocações, procura abafar, já que não pode revogá-lo, o art. 96 da Constituição Federal, que garante ao Juiz o exercício do magistério, e, numa verdadeira inversão de valores, transforma em demérito aquilo que, em qualquer outro país, seria um título dos mais lisongeiros.

Ninguém melhor do que Vossa Excelência, senhor Desembargador Presidente, figura-padrão da magistratura brasileira, filho, irmão e pai de magistrados, professor universitário e irmão do grande Mestre de direito Washington de Barros Monteiro, para dar o seu testemunho de que foi sábio o legislador ao permitir a acumulação dos dois cargos.

Êles, na verdade, se complementam e completam harmoniosamente, dando ao magistrado aquela profundidade de raciocínio que sòmente a argumentação doutrinária oferece, e armando o professor da vivência do direito, atuante, palpitante, fremente, que transborda dos pretórios através do jôrro da jurisprudência.

Em segundo lugar, o trabalho que acaba de ser editado, pela crítica que formula aos dispositivos vigentes e, principalmente, aos propostos, sem o necessário amadurecimento, inscreve-se no rol das contribuições da magistratura de São Paulo para o aprimoramento das instituições jurídicas pátrias num setor de fundamental importância.

Tornou-se o Tribunal de Justiça de São Paulo arauto e porta-voz de um movimento que, sob a sua liderança, acaba de resultar vitorioso, obrigando à retirada do verdadeiro atentado contra as mais caras, as mais arraigadas tradições da familia e do povo brasileiros, que se pretendia perpetrar sob o rótulo de Projeto de Código Civil!

Deve o decôro da cultura jurídica do País ao Tribunal de Justiça de São Paulo, pela sua crítica desassombrada e construtiva, alertando a opinião pública sôbre êrros e 
falhas, êsse serviços inestimável que foi o grito de "basta!" à improvisação até mesmo em matéria de Direito de Família.

Será graças a arrancadas como essas que São Paulo há de retomar, aos poucos, também no plano cultural, o lugar de relêvo, que é seu, no cenário nacional, e de que é mantido arredado há 36 anos!

Mas é o terceiro aspecto desta solenidade, por ser o mais caro aos meus sentimentos, como homem, que reservei para ressaltar em último lugar: a presença confortadora de tantos amigos e companheiros de ideal, a trazerem-me os tesouros inexauriveis de sua bondade, de sua benevolência, de sua simpatia.

Repete-se, há dois mil anos, que também os livros têm o seu destino.

Já não me é lícito duvidar que o de Adoção e Legitimação Adotiva será benigno.

Oxalá concorra para minorar as agruras de tantas inocentes criaturas que não podem continuar expiando pelo pecado, que não é delas, de terem vindo ao mundo!

Oxalá facilite a magistrados, membros do Ministério Público, advogados e pessoas bem dotadas de sentimento, em geral, a tarefa nobilíssima de colocar menores desamparados em lares substitutos.

Oxalá contribua para canalizar convenientemente a espontânea compassividade com que nossa gente procura socorrer os pequeninos, os desafortunados, os desassistidos.

As palavras carinhosas de Vossa Excelência, senhor Desembargador Presidente, e as do dr. Lauro Malheiros, intérprete do prestígio e do amparo da tradicional "Revista dos Tribunais", padrão de retidão e de honestidade, a confortadora e vibrante presença de tantos amigos, dão-me a certeza de que êste livro, que, como meus filhos e minha 
espôsa, constitui uma parcela da minha vida, é também uma partícula do meu coração, um pouco da minha alma, saberá realizar o seu destino, que é o de cooperar para a solução de um dos mais tormentosos problemas com que se defronta a civilização: o da infância abandonada! 